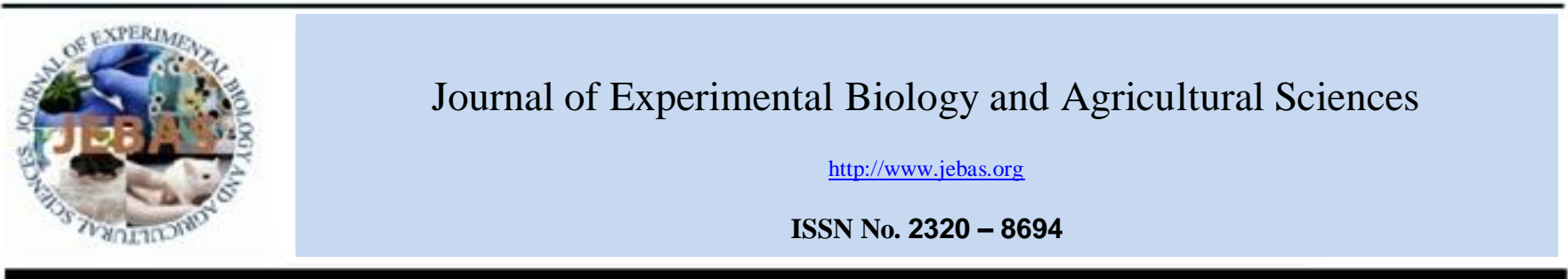

\title{
DECOMPOSITION APPROACH TO FORMATION OF ACCOUNTING AND ANALYTICAL SYSTEM OF COST MANAGEMENT IN AGRICULTURAL ENTERPRISES
}

\section{Viktor Vilenovich Govdya, Irina Nikolaevna Khromova, Nadezhda Konstantinovna Vasilieva, Yuriy Ivanovich Sigidov", Tatiana Nikolaevna Polutina}

Kuban State Agrarian University, Russia, 350044, Krasnodar, Kalinin Street, 13

Received - August 08, 2017; Revision - October 25, 2017; Accepted - December 15, 2017

Available Online - December 27, 2017

DOI: http://dx.doi.org/10.18006/2017.5(6).818.830

\section{KEYWORDS \\ Management accounting \\ Responsibility center \\ Cost management efficiency \\ Sugar-beet}

\section{ABSTRACT}

The formation of market relations and a growing competitive struggle stipulate the necessity of introduction of modern methods of cost management and control by the economic entities. The purpose of this research is to develop the methods of cost accounting and management in the field of industrial sugar-beet growing on the base of the decomposition formation of the management accounting system. For this, the empiric data of 168 agricultural enterprises were used, which allowed grouping these objects of research according to the level of specialization, concentration and intensification of production. A more profound research was performed in the economic entities with the maximal efficiency of the sugar-beet production that can be compared according to the level of the accounting process organization. As a result of solving of the set problems, the classification of the responsibility and cost centers was developed and the method of cost management accounting and calculation of sugar-beet products according to the responsibility centers of the organizations, taking into account the qualitative characteristics of manufactured products, was approved. The practical application of the developed measures gives the powerful capabilities for the formation of the more reliable information of the costs necessary for the efficient management of the studied branch.
\end{abstract}

* Corresponding author

E-mail: ysigidov@bk.ru (Yuriy Ivanovich Sigidov)

Peer review under responsibility of Journal of Experimental Biology and Agricultural Sciences.

Production and Hosting by Horizon Publisher India [HPI] (http://www.horizonpublisherindia.in/).

All rights reserved.
All the article published by Journal of Experimental Biology and Agricultural Sciences is licensed under a Creative Commons Attribution-NonCommercial 4.0 International License Based on a work at www.jebas.org.

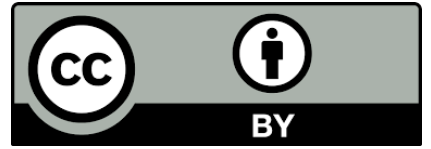




\section{Introduction}

The dynamics of the development of the modern economic relations in the national and international markets stipulate the necessity of the modernization of processes of production, management and prediction of the results of economic activity of their participants. The conditions of the innovative economy require the formation of the information system that qualitatively and timely provides relevant data to the management of organization for solution of tactic and strategic problems. The traditional tools of accounting, analysis and control should be actively integrated into this system (Abdel-Kader \& Luther, 2006).

Traditional information systems of accounting are aimed at the establishment of financial reports, data collection and consolidation. In order for information to be used by decision makers, accounting should be oriented towards business processes (Trigo et al., 2016).

Now the practice of management accounting is studied actively; it takes into account the impact of various factors of the business environment. At the same time, the estimation of the impact of the information, communication technologies, computer systems, integration processes within the frameworks of the economic entity on the development of the management accounting is performed (Mat et al., 2010).

This determines the significance of the complex system of registration and processing of information of costs and the results of the company's activity that includes its identification and analysis aimed to developed the new methods of control.

To provide accurate and operative estimation of the production prime cost and calculation of potential reserves of efficiency growth in production, there is a necessity to increase the informational and analytical capacities of the traditional methods of cost accounting and calculation of products in the management accounting system (Fullerton et al., 2013). The implementation of the mentioned measures gives the possibility to obtain the necessary data for planning, analysis and prediction of the results of activity of every economic entity of the agro-industrial complex.

Over the past decades, the role of the management accounting as a tool of the efficient management of organization has grown significantly. It determines the interest of many scientists when performing the research and estimation of various methods of management accounting from the point of view of the efficiency of their application in different economic formations (Lukka \& Granlund, 1996; Brierley et al., 2001).
Some studies confirm that when certain conditions of the economic environment are changed, the role of the management accounting is changed as well (Garg et al., 2004; Mat et al., 2010). Abo-Alazm Mohamed (2013) shares the same opinion resuming that the development of the production technologies, growing competition increase the role of the management accounting system when achieving the competitive advantages.

At the same time, the traditional methods of management accounting cannot always satisfy the inquiries of users of the accounting information (Ma \& Tayles, 2009). The modern economic conditions presuppose the process of active integration of the traditional tools of accounting, analysis and control into the complex accounting and analytical system of accumulation and processing of the obtained data. At the same time, the procedures of the functional and cost analysis of bench-marking, the system of target-costing are widely used, the analysis of the value chain is performed, the costs for the quality of the manufactured products are taken into account (Simon, 2006).

Modern studies in the field of the development of the management accounting prove that the formation of the additional money flows is closely connected to the wider and active introduction of the methods of cost management (Reid \& Smith, 2000). This is especially important in the conditions of the world financial crisis.

The questions of use of the maximally efficient tools of the cost management accounting are realized in two directions. On the first hand, it is necessary to reorient the managerial personnel of the economic entity towards the solving of problems of the modern economic system. While on the other hand, it is the improvement of the existing methods and the development of the new methods of management accounting including the methods of accounting and control of production costs for production and product cost determination (Stolyarova \& Bondarenko, 2010). Within the frameworks of the mentioned concept, the information flow will be formed reflecting the objective business information and allowing modeling the economy of the economic entity in general.

The active integration of the progressive managerial procedures into the existing systems determines the prerequisites for the determination of the process of calculation of the production prime cost as the main principle of the economic work organization (Yalcin, 2012).

This determines the high significance of the scientifically grounded cost determination in the estimation of the implementation of the set plans according to the level of prime cost, price determination, profitability, economic efficiency, innovative processes and the activity of the organization in general (Revellino \& Mouritsen, 2015). The competent approach to the use of materials obtained as a result of the calculations 
helps to search and mobilize the intra-productive reserves, decision-making concerning the level of concentration, specialization, intensification of production, improvement of the economic relations at the micro level (Govdya \& Degaltseva, 2015).

In our opinion, cost determination is a necessary process for the company control and one of the most significant aspects of the management accounting system. The retrospective analysis of the cost determination schemes showed that their main aim was the estimation of the reserves of the finished products, unfinished production at the beginning and at the end of the accounting period and revealing of profit, without providing at the same time the opportunity to use this information for the management purposes by the management of the organization (Weizmann, 1936). At the modern stage, these systems are more balanced and include a wide range of tools for the implementation of the managerial functions and tasks (Weißenberger \& Angelkort, 2011).

The cost management of an economic entity is a multisided and labor-intensive business process. As it covers most aspects of the production activity, it essentially characterizes the control of the whole activity of the enterprise. Basing upon the abovementioned facts, it should be noticed that the modern concept of cost accounting and calculation of the product prime cost is considered as the process of formation of the previous, current and future costs of the production activity of the enterprise in the conditions of the applied management system directed to the implementation of the set tasks (Khromova, 2014). The set system is complied with the main goals of the of cost management.

At the same time, the establishment of such a system entails high costs, which can be justified when using the data obtained and various decision-making tools. Otherwise, it makes no sense to bear the cost of such a system (Uyar \& Kuzey, 2016).

The results of work of the scientists in the studied field prove that most studies of the formation and development of the cost management accounting are shown in a summarized format, without profound analysis of peculiarities of the production technologies of the particular types of agricultural products. It stipulates the necessity and importance of study of the organizational and methodological aspects of formation of the accounting and analytical provision system of cost management process in the field of the industrial sugar-beet growing.

The scientific hypothesis of the performed research is in the presumption that the application of the decomposition approach to the formation of the management accounting system according to the financial responsibility centers and also the modernization and rationalization of the existing methods of cost accounting and estimation are required for the more efficient cost management of the agricultural production, accurate and operative formation of the prime cost.

The purpose of the scientific research is the grounding of the theoretical provisions and the development of the methodological provisions of the cost management accounting in the industrial sugar-beet production, preparation of the practical recommendations of building of the accounting and analytical provision system of the management processes on the base of the estimation of sugar-beet products taking into account the quality.

The object of the research is the methodological, organizational, economical provisions regarding the cost production accounting and sugar-beet prime cost determination in the agricultural organizations of the Russian Federation.

\section{Materials and Methods}

\subsection{Characteristics of sampling and data collection}

In the agro-industrial complex of the Russian Federation, the sugar-beet sub complex takes one of the main positions. The efficient interaction of all participants in the agro-industrial complex determines the efficiency of this branch. Krasnodar Krai, being one of the leading sugar-beet growing regions of the country, is provided with the powerful base for sugar-beet production.

When studying the population of agricultural enterprises of Krasnodar Krai, we used the method of statistical groups. This method allows determining the homogeneous populations, studying the structures of populations and changes occurring inside them and also solving of problems of study of the existing connections and dependencies.

For the scientific research, we selected 168 large and mediumsized sugar-beet growing agricultural organizations of Krasnodar Krai. The population excludes small enterprises and farms (farm enterprises) because they possess abnormal indicators of the group values.

As the characteristics according to which the population ranging of the objects of the research was performed, the values of concentration, specialization and intensification of the sugar-beet growing were distinguished. At the next stage of the research, the intervals of values of the varying characteristics were determined. The lower limit of the interval was a minimal value of characteristics in the interval, and the upper limit was its maximal value. As a result, the groups of organizations were determined possessing the maximal values of the economic efficiency indicators of the sugar-beet production. When implementing the 
method of statistical grouping, the following indicators were chosen as the studied ones:

1. Yield from 1 hectare is the most important indicator characterizing the level of use of agricultural land and largely determines the efficiency of agricultural enterprises;

2. Variable cost of 1 hundred products weights.

A feature of the crop sector is that the volume of production is known only after harvesting. At the end of the production cycle, ranking the constant and variable costs in relation to the volume of production is ineffective in making managerial decisions. In this regard, Russian economists consider it necessary to take the treated land in hectares during the growing season, and the volume of production in hundredweight during the harvesting period.

The variable costs vary linearly depending on the functional changes in activity. In relation to changes in crop areas, they include costs for seeds and planting stock, plant protection products, fertilizers, fuels and lubricants, salary for work performed, etc. In relation to the volume of production, the variable costs include salary for the products received, the cost of transportation services during the harvesting period, etc.

Accurate and timely accounting of the variable costs allows determining and controlling the production cost in the crop sector at each stage of the technological process and the responsibility centers.

3. Labor intensity of 1 hundredweight of products. This indicator characterizes the costs of living labor for the production and is calculated in natural meters. The labor intensity establishes a direct relationship between the volume of production and labor costs and allows comparing the labor costs for the same products at the responsibility centers.

4. Profit per 1 hectare of crops; this profit is formed on the basis of turnover from the sale of sugar beet and its production cost.
5. Profitability of production is determined by the ratio of profit from the sale of products to their cost.

For the grouping of the agricultural enterprises, auxiliary calculations were made based on the data of the Production Report, costs, production costs and sales of crop production, and the Sales Report on the agricultural products of each business entity.

With the use of the described method of scientific research, the following conclusions were formulated.

- One of the studied characteristics was the concentration of sugar-beet production characterized by the concentration of the land resources, facilities, and production means and determining the parameters of the economic efficiency. The grouping of agricultural enterprises according to the planting acreage of this crop allowed determining the tendency of changes of the basic economic indicators depending upon the level of its concentration (Table 1).

- The increase of the sugar-beet acreage was observed together with the increase of the profitability of production from $25.80 \%$ in the first group to $56.22 \%$ in the third one. The larger farms possess the bigger opportunities of concentration of the material and technical resources and that gives the possibility to perform the agro-technical actions in the recommended terms, use the modern technologies of the agricultural crop production.

- The results of the performed research allow resuming that increasing the production concentration creates the favorable conditions for the most rational use of the mechanization means that helps the growth of the labor productivity, reduction of prime costs and, as a result, the growth of the production profitability. The production concentration in the agricultural organizations is closely connected to the degree of its specialization. The key factor reflecting this level is the

Table 1 Economic efficiency of sugar-beet production according to the level of its concentration in the agricultural enterprises of Krasnodar Krai

\begin{tabular}{|lccccccc|}
$\begin{array}{l}\text { Group of objects acc. } \\
\text { to sugar-beet acreage } \\
\text { (ha) }\end{array}$ & $\begin{array}{c}\text { Number of } \\
\text { objects in } \\
\text { group }\end{array}$ & $\begin{array}{c}\text { Average crop } \\
\text { acreage per object } \\
\text { (ha) }\end{array}$ & $\begin{array}{c}\text { Yield from } \\
1 \text { ha (hwt) }\end{array}$ & $\begin{array}{c}\text { Prime cost } \\
1 \text { hwt } \\
\text { (Roubles) }\end{array}$ & $\begin{array}{c}\text { Labor Intensity Profit per 1 ha } \\
\text { per 1 hwt } \\
\text { (man-hour) }\end{array}$ & $\begin{array}{c}\text { Po crops } \\
\text { (Roubles) }\end{array}$ & $\begin{array}{c}\text { Profitability of } \\
\text { products (\%) }\end{array}$ \\
\hline Up to 500 & 76 & 257 & 490 & 108.6 & 0.10 & 7,328 & 25.80 \\
\hline From 501 to 1000 & 58 & 722 & 496 & 102.6 & 0.08 & 14,248 & 55.41 \\
\hline 1001 and more & 34 & 1444 & 502 & 94.8 & 0.05 & 17,878 & 56.22 \\
\hline Total and average & 168 & 658 & 498 & 100.1 & 0.06 & 14,636 & 50.65 \\
\hline
\end{tabular}

Journal of Experimental Biology and Agriculture Science http://www.jebas.org 
structure of marketable products.

- Studying the index of the entity specialization of the studied population on profit specific weight from the sale of the sugar-beet in the total volume of revenue from the sales of the plant growing branch, the conclusion was made that the economic efficiency of sugar-beet production increased together with the growth of its share in the structure of marketable products (Table 2).

- The obtained results prove that in the organizations referred to the third group, the growing of sugar-beet is more efficient and this is confirmed by the level of profitability- $61.49 \%$. The sugar-beet growing specialization in Krasnodar Krai is rational due to the reduction of the production costs when growing the sugar-beet with the simultaneous increase of their payback.

- The intensification of production is an integrated index reflecting the results of social and economic processes directed to the increase of production volumes, the increase in quality, the decrease in prime cost on the base of introduction of the new technologies, varieties of growing crops and other measures being a part of the scientific and technical progress (Khromova, 2014).

- The group of population of the agricultural organizations according to the level of the production costs per 1 hectare of the sugar-beet acreage allowed determining the interconnection of the change of this index and the efficiency of the crop production (Table 3 ).

- The results of the performed research prove that sugarbeet growing gets the maximal economic efficiency when reaching the level of production costs of 40 thousand roubles per 1 hectare of crops. The application of various measures and means of intensification of the sugar-beer sub-complex is required for an increase in the quality of the raw material for the industrial processing and implementation of the new intensive technologies of crop production. The practicability of the costs' increase of production resources when growing the crop shall be determined from the point of view of the national economic approach to their growing. This

Table 2 Economic efficiency of sugar-beet production according to the level of its specialization in the agricultural organizations of Krasnodar Krai

\begin{tabular}{|lccccccc|}
\hline $\begin{array}{c}\text { Groups of objects on } \\
\text { sugar-beet specific } \\
\text { weight } \\
\text { in structure of } \\
\text { marketable products } \\
(\%)\end{array}$ & $\begin{array}{c}\text { Number of objects } \\
\text { in group }\end{array}$ & $\begin{array}{c}\text { Sugar-beet specific } \\
\text { weight } \\
\text { in structure of } \\
\text { marketable products, } \\
(\%)\end{array}$ & $\begin{array}{c}\text { Yield per } \\
\text { 1 ha (hwt) }\end{array}$ & $\begin{array}{c}\text { Prime cost of 1 Labor Intensity } \\
\text { hwt (Roubles) }\end{array}$ & $\begin{array}{c}\text { Profit per 1 ha } 1 \text { hwt } \\
\text { of crops } \\
\text { (man-hour) }\end{array}$ & $\begin{array}{c}\text { Profitability of } \\
\text { products (\%) }\end{array}$ \\
\hline Up to 9 & 76 & 6 & 465 & 109.3 & 0.07 & 4983 & 29.48 \\
\hline From 10 to 20 & 36 & 16 & 495 & 99.5 & 0.05 & 11,576 & 42.02 \\
\hline 21 and more & 56 & 32 & 527 & 93.5 & 0.06 & 24,537 & 61.49 \\
\hline Total and average & 168 & 16 & 498 & 100.1 & 0.06 & 14,636 & 50.65 \\
\hline
\end{tabular}

Table 3 Economic efficiency of the sugar-beet production according to the level of its intensification on the agricultural

\begin{tabular}{|lcccccccc|}
$\begin{array}{c}\text { Groups of objects } \\
\text { acc.to costs per 1 ha } \\
\text { of sugar-beet crops } \\
\text { (Thousand roubles) }\end{array}$ & $\begin{array}{c}\text { Number of } \\
\text { objects in } \\
\text { group }\end{array}$ & $\begin{array}{c}\text { Average costs } \\
\text { per 1 ha } \\
\text { acc. to grou, } \\
\text { (Thousand } \\
\text { roubles) }\end{array}$ & $\begin{array}{c}\text { Yield per } \\
1 \text { ha (hwt) }\end{array}$ & $\begin{array}{c}\text { Prime cost of 1 } \\
\text { hwt (Roubles) }\end{array}$ & $\begin{array}{c}\text { Labor Intensity } \\
\text { per 1 hwt } \\
\text { (man-hour) }\end{array}$ & $\begin{array}{c}\text { Profit per 1 ha of } \\
\text { crops (Roubles) }\end{array}$ & $\begin{array}{c}\text { Profitability of } \\
\text { products (\%) }\end{array}$ \\
\hline Up to 40 & 54 & 33.38 & 467 & 71.4 & 0.06 & 20,898 & 109.09 \\
\hline from 41 to 50 & 44 & 44.42 & 497 & 89.3 & 0.07 & 22,562 & 75.36 \\
\hline 51 and more & 70 & 64.83 & 520 & 124.6 & 0.06 & 5,854 & 16.49 \\
\hline Total and average & 168 & 49.85 & 498 & 100.1 & 0.06 & 14,636 & 50.65 \\
\hline
\end{tabular}

Journal of Experimental Biology and Agriculture Science http://www.jebas.org 
circumstance, in its turn, influences the formation of system of accounting and management of costs in this branch.

\subsection{Tools of research}

Within the framework of the studied population, 33 organizations were chosen with the indexes of the sugar-beet production efficiency that could be compared according to the size, level of specialization and intensification of production. Later, the research of the organizational structure of control of the mentioned objects to reveal the potential for the decomposition formation of the management accounting system was performed. The acting structure allows performing the general and particular control functions, providing the most acceptable vertical and horizontal interconnections. The estimation of the efficiency of the enterprise organizational structure is a key aspect for the managerial decision making that allows determining the degree of the development of the existing system.

Also during the process of research, the peculiarities of the accounting process organization and the practice of application of the management accounting tools were studied. For this, the test of estimation of the accounting system was performed that consisted of 75 points grouped in the following blocks: system of cost accounting and estimation, budgeting system, system of decision-making, estimation of efficiency.

\section{Results and Discussion}

In the modern economy, the key task of the organizational management is to develop the strategy of its economic development. At the same time, the role of the management accounting is growing. It becomes the obligatory subsystem of control of the economic entity corresponding to the chosen strategic direction of development and promoting the consolidation of the personnel role in the decision-making. It determines the importance of the organization of decentralized control at the enterprise presupposing the delegation of the corresponding authorities and responsibility between different levels of hierarchy.

3.1 Decomposition formation of the management accounting system on the base of the executed business processes in the organizations of the agroindustrial complex

The decentralized system of control of the economic entity presupposes the realization of the methodology of the management accounting based upon the control of results of functioning of the responsibility centers. The mentioned system possesses the following advantages: the heads of the business segments possess the bigger massive of information concerning the conditions of operation in situ; the work of personnel as a result of its own initiative becomes maximally motivated; the degree of personnel individual responsibility of the responsibility centers is increased for the achievement of the set industrial results (Horngren et al., 2005).

At the same time, the management accounting data and accounting procedures play an important role in the context of making tactical and strategic decisions by companies with a complex organizational structure (Nielsen et al., 2015).

The decomposition of the financial responsibility centers is determined by the specific peculiarities of activity of the particular economic entity, its goals, tasks and planned indexes (Kostyukova \& Bashkatova, 2011). The efficient functioning of the cost management system according to the responsibility centers in the agricultural organizations is based upon the following factors:

1. The acting organizational and production structure of the enterprise shall be a base of distinguishing of the responsibility centers.

2. The base of classification of the responsibility centers is a completedprocess procedure, unchanged number of employees, volume of production means.

3. The responsibility center has the authorities to form independently the production program based upon the principles of self-repayment and self-financing.

4. When organizing the cost accounting system, it is necessary to provide the correctness of referring of the corresponding costs to the responsibility center.

5. The system of personnel motivation shall take into account only those indexes that depend upon the activity of the head and employees of the certain center. The planning shall take into account the compliance of the responsibility and authorities.

6. Every responsibility center shall have its own system of internal control.

7. The costs for the management system organization of the responsibility centers shall not exceed the level of income from its introduction.

Due to this, we offered the decomposition approach to the organization of management accounting system of sugar-beet growing organizations that increased the efficiency of their operation. At the same time, the optimal structure of the correlation "costs for organization of system efficiency of system functioning" was observed (Figure 1).

Our research presupposes the determination of an agricultural organization as a center of profit and investments. The indexes of the sales' volume, sale prices, constant and variable costs characterize the efficiency of the profit center functioning. The 
result of center activity is estimated according to the index of profit. The activity of the investment center is directed to the provision of the returns on capital and investments.

Later the decomposition of the responsibility centers is represented according to the types of activity of organization (main, auxiliary); types of responsibility centers (centers of costs, revenue, management); according to the types of the business processes executed (management, supply, sale, main and auxiliary production) (Khromova, 2014).

The structure offered by the authors allowed determining the main functions of the responsibility centers of the sugar-beet organization and organizing the accounting system and cost management without breaking of the hierarchical connections between different levels of control providing at the same time the functioning of system of accounting and analytical provision of production.

\subsection{Classification of cost centers in the agricultural enterprises}

The developed decomposition of the responsibility centers presupposes the distinguishing of the cost centers. This circumstance is stipulated by the possibility of output of several types of products by the industrial subdivisions of the organization. The management accounting system that provides the localization of costs according to their cost centers and items of estimation will allow forming the maximally objective information for the efficient managerial decision-making.

When organizing the set system, we offered to use the elements of financial accounting and data coding system as a base to provide the accounting in the united information field to minimize the number of errors.

The use of coding in the management accounting allows identifying various accounting objects definitely by all the participants of the process of planning, control, analysis,

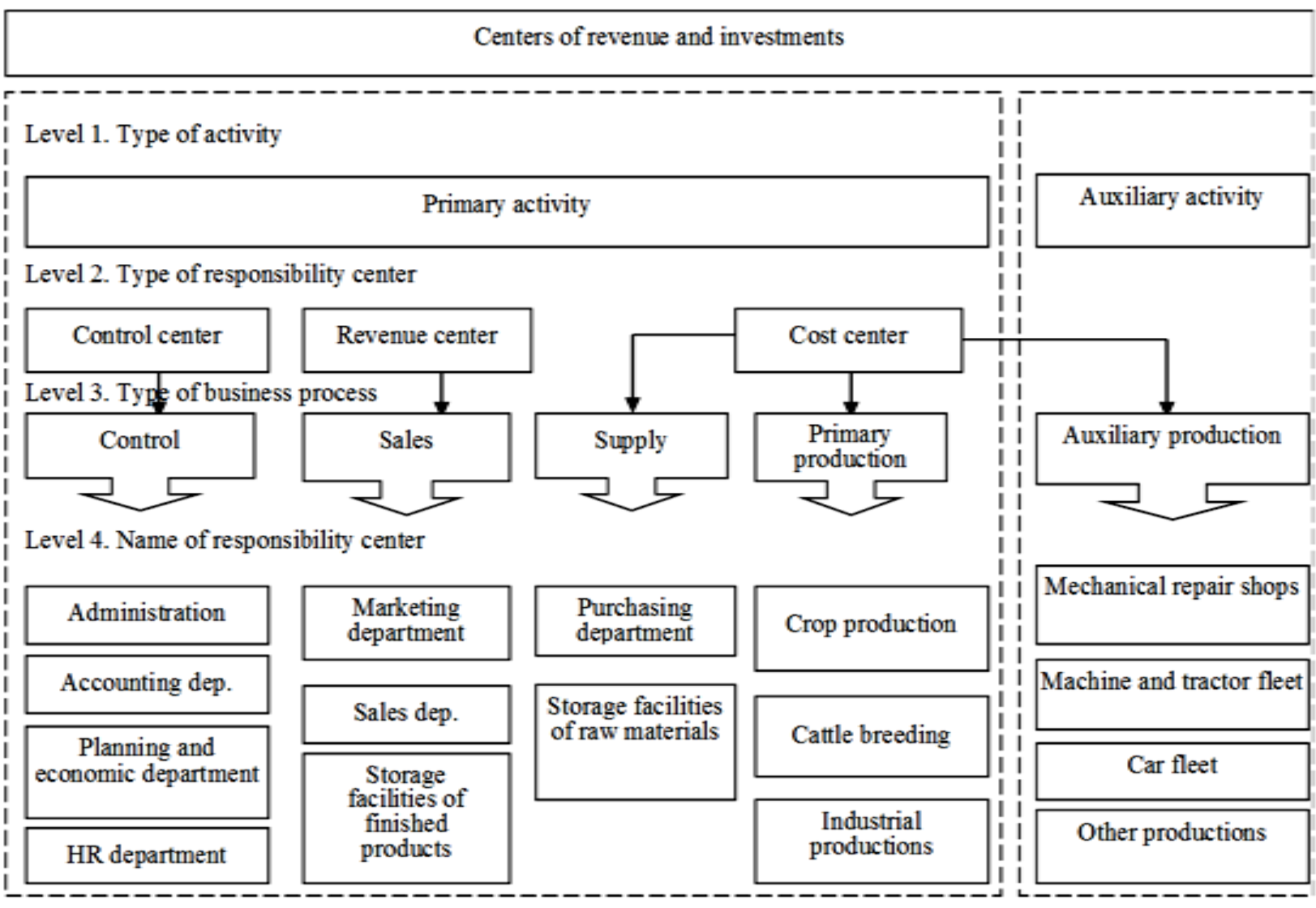

Figure 1 Decomposition of responsibility centers in the organizations of agroindustrial complex 
stimulation. The number of classifiers is determined by the organization independently and takes into account the peculiarities of the activity and their own needs. In case of necessity, the multilevel coding system is used for the corresponding specification of the accounting objects.
The offered grouping of cost centers and responsibility centers in the agricultural enterprises is shown in Table 4. The coding system developed by the authors is based upon the application of numbering of analytical account of the accounting. The following symbols determine the responsibility center according to the

Table 4 Classification of cost centers in the organizations of agro-industrial complex

\begin{tabular}{|c|c|c|c|}
\hline \multirow[t]{2}{*}{ Type of business process } & $\begin{array}{l}\text { Type of responsibility center and cost } \\
\text { center }\end{array}$ & $\begin{array}{l}\text { Account, subaccount } \\
\text { of accounting }\end{array}$ & \multirow[t]{2}{*}{$\begin{array}{l}\text { Coding of responsibility } \\
\text { centers and cost centers }\end{array}$} \\
\hline & \multicolumn{2}{|c|}{ 1. Type of primary activity } & \\
\hline \multirow{4}{*}{ Process of control } & Administration & 26 & 01.01 \\
\hline & Accounting department & 26 & 01.02 \\
\hline & Economic service & 26 & 01.03 \\
\hline & Human resources department & 26 & 01.04 \\
\hline \multirow{3}{*}{ Process of sales } & Marketing department & 44 & 02.01 \\
\hline & Sales department & 44 & 02.02 \\
\hline & Storage facilities of products & 44 & 02.03 \\
\hline \multirow{2}{*}{ Process of supply } & Purchasing department & 26 & 03.01 \\
\hline & Storage facilities of raw materials & 26 & 03.02 \\
\hline \multirow{13}{*}{$\begin{array}{l}\text { Process of primary } \\
\text { production }\end{array}$} & 1. Crop production & 20.1 & 04.01 \\
\hline & - center No. 1 & - & 04.01 .1 \\
\hline & - rise growing & - & 04.01 .1 .1 \\
\hline & - sugar-beet growing & - & 04.01 .1 .2 \\
\hline & - centerNo. 2 & - & 04.01 .2 \\
\hline & 2. Cattle breeding & 20.2 & 04.02 \\
\hline & - center of beef cattle breeding & - & 04.02 .1 \\
\hline & - center of dairy cattle breeding & - & 04.02 .2 \\
\hline & - center of sheep breeding & & \\
\hline & 3. Industrial production & 20.3 & 04.03 \\
\hline & - flour manufacture & - & 04.03 .1 \\
\hline & - milk processing workshop & - & 04.03 .2 \\
\hline & - bakery & - & 04.03 .3 \\
\hline \multicolumn{4}{|c|}{ 2. Auxiliary activity } \\
\hline \multirow{5}{*}{$\begin{array}{l}\text { Process of auxiliary } \\
\text { production }\end{array}$} & Repair workshops & 23.1 & 05.01 \\
\hline & Machine and tractor fleet & 23.3 & 05.02 \\
\hline & Freight and car traffic & 23.4 & 05.03 \\
\hline & Electrical shop & 23.5 & 05.04 \\
\hline & Water supply & 23.6 & 05.05 \\
\hline
\end{tabular}


business processes performed in the organization, sequence numbers of the cost centers in the structure of every center. The mentioned classifier can be supplemented basing upon the necessity and priority level.

The decentralization of the organization management system stipulates the necessity to use the transfer price formation. This mechanism allows coordinating the activity of the responsibility centers, determining the directions of development and the personnel motivation system of these centers.

level of cost centers (Bouwens \& Steens, 2016). At the same time, they shall take into account the qualitative characteristics of the sold products for the economic grounding of its profitability. In sugar-beet growing organizations, it is reasonable to set the transfer prices on the base of the level of sugar content of the sugar-beet. The system of transfer pricing is a powerful control tool of the organization activity and it allows estimating the economic effect of functioning of every responsibility center.

3.3 Method of prime cost estimation of sugar-beet depending upon the level of its quality according to the responsibility centers

The quality control of agricultural products that are the raw material for industrial processing requires the availability of the relevant information of the main qualitative characteristics. The management accounting shall form and accumulate the set data for the active introduction of the quality management system in the organization and for the corresponding managerial decisionmaking (Trubilin, 2009).

The main index characterizing the quality level of sugar-beet is sugar content. It determines the level of the sugar degree in the root crops. The organization of the management accounting according to the responsibility center taking into account this characteristic will allow improving the analytical functions of accounting and forming a more accurate system of accounting and analytical provision of the cost management process.

The offered method presupposes the distribution of the production costs when growing the sugar-beet according to the responsibility centers taking the products as an object in terms of the basic sugar degree (Table 5).

The average value of this index is accepted as a basic sugar degree within the framework of the studied organization $(15.36 \%)$. When dividing the total sum of costs by the volume of products of basic conditions, the prime cost of the product unit is determined taking into account its quality. The acting method does not presuppose the determination of the prime cost of products within the framework of the distinguished responsibility centers and forms it only at the level of organization in general. Thus, the prime cost value of the unit of estimated products is 132.28 roubles per 1 hwt.

The offered method allows obtaining the information of the sugar beet prime cost according to every responsibility center. The

Table 5 Distribution of costs for sugar-beet production depending upon its quality in JSC Chapaevstud farm, Krasnodar Krai

\begin{tabular}{|c|c|c|c|c|c|c|}
\hline \multirow[b]{2}{*}{ Index } & \multicolumn{5}{|c|}{ Responsibility center } & \multirow[b]{2}{*}{ Total and average } \\
\hline & $\begin{array}{l}\text { center } \\
\text { No. } 1\end{array}$ & $\begin{array}{l}\text { center } \\
\text { No. } 2\end{array}$ & $\begin{array}{l}\text { center } \\
\text { No. } 3\end{array}$ & $\begin{array}{l}\text { center } \\
\text { No. } 4\end{array}$ & $\begin{array}{l}\text { center } \\
\text { No. } 5\end{array}$ & \\
\hline Gross weight after-cleaning (hwt) & 62,381 & 109,525 & 79,214 & 82,792 & 148,077 & 481,989 \\
\hline Sugar content $(\%)$ & 14.07 & 15.92 & 15.11 & 15.34 & 16.35 & 15.36 \\
\hline $\begin{array}{l}\text { Standard weight taking into account quality, } \\
\text { hwt }\end{array}$ & 57,149 & 113,518 & 77,925 & 75,776 & 157,621 & 481,989 \\
\hline $\begin{array}{l}\text { Actual costs of responsibility center } \\
\text { (Roubles) }\end{array}$ & $8,251,924$ & $14,488,258$ & $10,478,638$ & $10,951,946$ & $19,588,019$ & $63,758,786$ \\
\hline \multicolumn{7}{|l|}{$\begin{array}{l}\text { Actual prime costs of } 1 \mathrm{hwt} \text { of sugar-beet } \\
\text { acc.to responsibility center, roubles }\end{array}$} \\
\hline (acting method) & - & - & - & - & - & 132.28 \\
\hline Offered method taking into account quality & 144.39 & 127.63 & 134.08 & 131.05 & 124.27 & 132.28 \\
\hline Actual production costs (Roubles) & $8,674,556$ & $14,886,879$ & $10,914,259$ & $11,371,530$ & $19,910,864$ & $65,758,089$ \\
\hline \multicolumn{7}{|l|}{$\begin{array}{l}\text { Actual manufacturing cost of } 1 \text { hwt of sugar- } \\
\text { beet, roubles }\end{array}$} \\
\hline ( acting method) & - & - & - & - & - & 136.43 \\
\hline offered method taking into account quality & 151.79 & 131.14 & 140.06 & 150.07 & 126.32 & 136.43 \\
\hline
\end{tabular}

Journal of Experimental Biology and Agriculture Science http://www.jebas.org 
maximal level of prime cost, noted in the plant growing subdivision No. 1, is stipulated by the lowest level of sugar degree of products $(14.07 \%)$. The studies show that the increase in the level of the main qualitative parameter of sugar-beet leads to the reduction in the level of production costs per the unit of products. Thus, the minimal level of prime cost is noted at the plant growing subdivision No. 5 and it is 124.27 roubles. At the same time, this responsibility center provided the level of sugar content of $16.35 \%$, whichis the best result within the framework of the studied organization.

Thus, the level of prime cost of sugar-beet products depends directly upon the sugar degree of the obtained root crops.

The main generalizing index of the production economic efficiency is economic profitability. The estimation of this index is necessary for decision-making in the field of planning, investment, result estimation of the responsibility centers.

The analysis of the production efficiency and sugar-beet processing in the studied organization is shown in Table 6. In the agricultural enterprises in the Russian Federation, the accounting methodology for costs and yield of crop production does not imply the calculation of the economic efficiency of production on the responsibility centers. The actual cost price and profitability of the products are determined as a whole by the enterprise; this process complicates making the managerial decisions.

The offered method presupposes the application of the transfer pricing when determining the sugar-beet sale price with different levels of quality. This will establish an evaluation system for the performance of each responsibility center. It is most reasonable to estimate the transfer prices of the products on the base of the market prices.

The table contains data on the sale of beet products in general for the enterprise and for each responsibility center. The final value of this indicator corresponds to the form of financial report "Production Balance Sheet".

Digestion of sugar beet is the main quality indicator of the products. It is determined in laboratory conditions both for each unit and on average for the business entity. Information on cost, sales price, and profitability level are presented taking into account the level of the quality and reflect the average values of the indicators.

As a result of the calculations, it was established that in the subdivision No. 5 of JSC Chapaev Stud farm, the sugar-beet sale price gets the maximal value (193.73 rubles), which is the consequence of the achievement of the best production results in the field of quality of the produced raw material. The lowest price was set in the responsibility center that obtained the minimal sugar content of the sugar-beet. The mentioned dynamics determine the direct dependence of the quality level of products and the economic profitability of their production.

When estimating the participation of every financial responsibility center in the achievement of the profit from the raw material processing on a give-and-take basis, it is necessary to take into

Table 6 Estimation of economic profitability of the sugar-beet production according to the responsibility centers in JSC

\begin{tabular}{|c|c|c|c|c|c|c|}
\hline Index & $\begin{array}{l}\text { center } \\
\text { No. } 1\end{array}$ & $\begin{array}{l}\text { center } \\
\text { No. } 2\end{array}$ & $\begin{array}{c}\text { nsibility } \\
\text { center } \\
\text { No. } 3\end{array}$ & $\begin{array}{l}\text { center } \\
\text { No. } 4\end{array}$ & $\begin{array}{l}\text { center } \\
\text { No. } 5\end{array}$ & $\begin{array}{l}\text { Total and } \\
\text { average }\end{array}$ \\
\hline Gross weight of sold sugar-beet (hwt) & 20,542 & 54,672 & 24,096 & 16,559 & 30,654 & 146.523 \\
\hline Sugar content ( $\%)$ & 14.07 & 15.92 & 15.11 & 15.34 & 16.35 & 15.36 \\
\hline \multicolumn{7}{|l|}{$\begin{array}{l}\text { Actual prime cost of } 1 \text { hwt of sugar-beet acc.to } \\
\text { responsibility center, roubles }\end{array}$} \\
\hline Offered method taking into account quality & 144.39 & 127.63 & 134.08 & 131.05 & 124.27 & 132.28 \\
\hline $\begin{array}{l}\text { Conditional sale price of } 1 \mathrm{hwt} \text { of sugar-beet, } \\
\text { roubles (acting method) }\end{array}$ & - & - & - & - & - & 182.00 \\
\hline Offered method taking into account quality & 166.71 & 188.64 & 179.04 & 181.76 & 193.73 & 182.00 \\
\hline \multicolumn{7}{|l|}{$\begin{array}{l}\text { Conditional economic proficiency of sugar- } \\
\text { beet production }(\%)\end{array}$} \\
\hline By acting method & - & - & - & - & - & 37.59 \\
\hline Offered method taking into account quality & 15.46 & 47.80 & 33.53 & 38.71 & 55.89 & 37.59 \\
\hline
\end{tabular}


Table 7 Economic efficiency estimation of sugar manufactured from the raw material from JSC Chapaev Stud farm, Krasnodar Krai, on a give-and-take basis

\begin{tabular}{|c|c|c|c|c|c|c|}
\hline Index & $\begin{array}{l}\text { center } \\
\text { No. } 1\end{array}$ & $\begin{array}{l}\text { center } \\
\text { No. } 2\end{array}$ & $\begin{array}{c}\text { nsibility } \\
\text { center } \\
\text { No. } 3\end{array}$ & $\begin{array}{l}\text { center } \\
\text { No. } 4\end{array}$ & $\begin{array}{l}\text { center } \\
\text { No.\# } 5\end{array}$ & $\begin{array}{l}\text { Total and } \\
\text { average }\end{array}$ \\
\hline Mass of the sugar beet produced for tolling (hwt) & 41,839 & 54,853 & 55,118 & 66,233 & 117,423 & 335,466 \\
\hline Payment for grinding $(\%)$ & 30 & 30 & 30 & 30 & 30 & 30 \\
\hline Mass of sugar beet minus the prick harvest (hwt) & 29,287 & 38,397 & 38,583 & 46,363 & 82,196 & 234,826 \\
\hline Loss of beet mass during storage (\%) & 2.44 & 2.44 & 2.44 & 2.44 & 2.44 & 2.44 \\
\hline $\begin{array}{l}\text { Gross weight of sugar-beet obtained for processing } \\
\text { (hwt) }\end{array}$ & 28,573 & 37,460 & 37,641 & 45,232 & 80,191 & 229,096 \\
\hline Sugar content $(\%)$ & 14.07 & 15.92 & 15.11 & 15.34 & 16.35 & 15.36 \\
\hline Sugar losses during processing $(\%)$ & 2.96 & 2.96 & 2.96 & 2.96 & 2.96 & 2.96 \\
\hline Sugar output $(\%)$ & 11.11 & 12.96 & 12.15 & 12.38 & 13.39 & 12.40 \\
\hline Conditional amount of sugar (hwt) & 3,174 & 4,855 & 4,573 & 5,600 & 10,738 & 28,408 \\
\hline Sale price of 1 hwt of sugar (Roubles) & 1,902 & 1,902 & 1,902 & 1,902 & 1,902 & 1,902 \\
\hline \multicolumn{7}{|l|}{$\begin{array}{l}\text { Actual prime cost of } 1 \text { hwt of sugar-beet acc.to } \\
\text { responsibility center (roubles) }\end{array}$} \\
\hline By acting method & - & - & - & - & - & 132.28 \\
\hline Offered method taking into account quality & 144.39 & 127.63 & 134.08 & 131.05 & 124.27 & 132.28 \\
\hline \multicolumn{7}{|l|}{$\begin{array}{l}\text { Actual prime cost of processing services of } 1 \mathrm{hwt} \\
\text { of sugar-beet (Roubles) }\end{array}$} \\
\hline By acting method & - & - & - & - & - & 58.11 \\
\hline offered method taking into account quality & 63.43 & 56.07 & 58.90 & 57.57 & 54.59 & 58.11 \\
\hline \multicolumn{7}{|l|}{$\begin{array}{l}\text { Conditional economic efficiency } \\
\text { (unprofitability) of sugar production (\%) }\end{array}$} \\
\hline By acting method & - & - & - & - & - & 21.76 \\
\hline Offered method taking into account quality & 1.58 & 29.90 & 15.91 & 9.37 & 37.84 & 21.76 \\
\hline
\end{tabular}

account the quality level of the raw material (Table 7).

The processing of the produced sugar-beet on a give-and-take basis presupposes the value setting of payment for processing volume of raw material that is at the disposal of the sugar-beet manufacturer as the payment. At the processing enterprises of the region, this payment for processing is set in the amount of $30 \%$.

The biological properties of sugar beet are characterized by loss of mass during storage. In the process of research, we determined this indicator at a rate of $2.44 \%$. This circumstance causes a reduction in the physical weight of products during processing.

Based on the actual level of sugar beet digestion and average sugar losses during processing $(2.96 \%)$, the conditional amount of sugar produced is calculated. This indicator has a conditional value, since the current accounting system does not involve calculation of the production of sugar for each unit. The specified value is calculated in the whole for the enterprise.

In this regard, the proposed methodology provides for determining the actual cost of sugar beet, services for its processing, and profitability of sugar for each responsibility center on the basis of the quality characteristics of products. The results of the study indicate that the highest output of the finished product of processing was observed in the plant-growing subdivision No.5, which provided the maximal sugar degree of the sugar-beet. The conditional output of sugar in this responsibility center was $13.19 \%$ from the total amount of products accepted for processing. The minimal values of the sugar output were registered in the center No. $1(11.11 \%)$.

\section{Journal of Experimental Biology and Agriculture Science} http://www.jebas.org 
The set dynamics determined the change of the economic efficiency level of sugar production of every responsibility center. The highest level of efficiency of the sugar-beet processing was registered in the subdivision No. 5 at the maximal quality level of the manufactured raw material. In the subdivision No. 1, the processing of sugar-beet was unprofitable due to its low quality.

The offered organizational and methodological aspects of the losses accounting and determination of the sugar-beet prime cost according to the responsibility centers based upon the estimation of the sugar content level allow determining the efficiency of functioning of every responsibility center of the organization, evaluating the contribution of each of them into the formation of profit of the economic entity and controlling the revealed deviations.

These measures improve the efficiency of the cost management system and form the information necessary for decision-making.

\section{Conclusion}

As a result of the performed scientific research, the authors developed the theoretical and methodological tools, the practical application of which allowed providing the coordination and optimization of costs within the framework of the economic activity of the organization.

The decentralization of control is a qualitative base for formation of the efficient cost control system that presupposes the delegation of the authority to the heads of different levels In this regard, the decomposition of the responsibility centers of the agricultural enterprises based upon the cost localization - and cost centers allows forming the maximally transparent and informative system. The research proved also the necessity of quality improvement of the manufactured sugar-beet products, and the methods of prime cost determination of products were offered that took this aspect into account.

For improvement of the organizational and methodological framework of the cost management accounting and determination of sugar-beet products in the agricultural enterprises, it is recommended to apply the offered algorithm of the decomposition formation of the system of accounting and analytical provision of the cost management process. This algorithm provides for the allocation of financial responsibility centers in the enterprise, taking into account the specifics of its organizational and managerial structure; the definition of the evaluation system for each center is based on the evaluation of the product quality.

The conducted scientific research is aimed at substantiating the advantages of applying various methods of cost accounting and developing recommendations for their implementation. The proposed measures are partially used in the accounting activities of agricultural entities in the Krasnodar Krai.

As a result of the research, we determined the priority directions for its further development. When considering the methodological aspect of functioning of the cost management accounting and estimation of sugar-beet products, we studied the population of average and large agricultural organizations. To intensify the empiric part of research the analysis is possible according to the population of entities of all categories. As the questions for the further research, we should mention the study of the problems of integration of the offered system of sugar-beet products' cost determination and various systems of accounting and cost management (standard-cost, direct-costing, target-costing, etc.) as the specified information can be useful for the users when installing and introducing the system of management accounting in the organization.

\section{Acknowledgements}

We express profound gratitude to Kostyukova Elena Ivanovna, Doctor of Economic Science, professor of Stavropol State Agrarian University, PostnikovaLyubovValeryevna, Candidate of Economic Sciences, Associate Professor of the Russian State Agrarian University - Moscow Timiryazev Agricultural Academy, Belova Marina Valentinovna, Candidate of Economic Sciences, Associate Professor of the Plekhanov Russian Economic University for the scientifically grounded comments formulated during discussion of the obtained results and the critics of the scientific research.

\section{Conflict of Interest}

Authors would hereby like to declare that there is no conflict of interests that could possibly arise.

\section{References}

Abdel-Kader M, Luther R (2006) Management Accounting Practices in the British Food and Drinks Industry. British Food Journal 108: 336-357. DOI:10.1108/00070700610661321

Abo-Alazm Mohamed F (2013) Changes in the Business Environment and the Level of Management Accounting Practices in Egypt: A Case Study. Journal of American Science 9: 78-89.

Bouwens J, Steens B (2016) Full-cost transfer pricing and cost management. Journal of Management Accounting Research 28: 63-81.DOI:10.2308/jmar-51390.

Brierley JA, Cowton CJ, Drury C (2010) Research into Product Costing Practice: A European Perspective. European Accounting Review 10: 215-256. DOI:10.1080/09638180126635 
Fullerton R, Kennedy F, Widener S (2013) Management Accounting and Control Practices in a Lean Manufacturing Environment. Accounting, Organizations and Society 38 : 50-71. DOI:10.1016/j.aos.2012.10.001

Garg A, Ghosh D, Halper H (2004) Best Practices in Management Accounting. Journal of Cost Management 18: 21-25.

Govdya VV, Degaltseva ZV (2015) Development of Management Accounting in Innovative Economy. Economy and Entrepreneurship $1: 681-685$.

Horngren CT, Foster J, Datar S (2005) Upravlencheskiiuchet [Management Accounting. Saint Petersburg: Piter.

Khromova IN

Mekhanizmformirovaniyasebestoimostiproduktsiisveklovodstva $v$ upravlencheskomuchete (dissertatsiya ... kandidataekonomicheskikhnauk) [Mechanism of Prime Cost Formation of Sugar-Beet Production in Management Accounting (Ph.D. Thesis)]. Retrieved June 30, 2017, from http://dlib.rsl.ru/01007523654

Kostyukova EI, Bashkatova TA (2011) Organizatsionnometodicheskieosnovyfunktsionirovaniyasistemyupravlencheskogo ucheta [Organizational and Methodological Fundamentals of Functioning of a Management Accounting System]. Mezhdunarodnyibukhgalterskiiuchet, 36, 12-17.20.2

Lukka K, Granlund M (1996) Cost Accounting in Finland: Current Practice and Trends of Development. The European Accounting Review 5: 128. DOI:10.1080/09638189600000001

Ma Y, Tayles M (2009). On the Emergence of Strategic Management Accounting: An Institutional Perspective. Accounting and Business Research 39: 473-495. DOI:10.1080/00014788.2009.9663379

Mat TZT, Smith M, Djajadikerta H (2010) Management Accounting and Organizational Change: An Exploratory Study in Malaysian Manufacturing Firms. Journal of Applied Management Accounting Research 8: 51-80.

Nielsen LB, Mitchel F, Nørreklit H (2015) Management accounting and decision making: Two case studies of outsourcing. Accounting Forum 39 : 64-82. DOI:10.1016/j.accfor.2014.10.005.
Reid GC, Smith JA (2000) The Impact of Contingencies on Management Accounting System Development. Management Accounting Research 11: 427-450. DOI:10.1006/mare.2000.0140

Revellino S, Mouritsen J (2015) Accounting as an Engine: The Performativity of Calculative Practices and the Dynamics of Innovation. Management Accounting Research 28: 31-49. DOI:10.1016/j.mar.2015.04.005

Simon C (2006) A Cross-Industry Comparison of Strategic Management Accounting Practices: An Exploratory Study. Economic and Business Review 8: 279-298.

Stolyarova MA, Bondarenko LV (2010) Upravlencheskiiuchetinnovatsionnoideyatelnosti [Management Accounting of Innovative Activity]. Bukhuchet $\mathrm{v}$ selskomkhozyaistve $1: 27-35$.

Trigo A, Belfo F, PérezEstébanez R (2016).Accounting Information Systems: Evolving towards a Business Process Oriented Accounting. Procedia Computer Science 100, 987-994. DOI:10.1016/j.procs.2016.09.264.

Trubilin, AI

(2009)

Organizatsiyaupravlencheskogouchetapotsentramotvetstvennostii mestamformirovaniyazatrat [Concept of Introduction of Management Accounting Mechanism into the Accounting Practice of Agricultural Enterprises]. Bukhgalterskiiuchet, 9, 2433.

Uyar A, Kuzey C (2016) Does management accounting mediate the relationship between cost system design and performance? Advances in Accounting 35: 170-176. DOI:10.1016/j.adiac.2016.06.004.

Weißenberger BE, Angelkort H (2011) Integration of Financial and Management Accounting Systems: The Mediating Influence of a Consistent Financial Language on Controllership Effectiveness. Management Accounting Research 22: 160-180. DOI: 10.1016/j.mar.2011.03.003

Weizmann RY (1936) Kursucheta [Course of accounting ( $2^{\text {nd }}$ ed.). Moscow: Soyuzorgizdat.

Yalcin S (2012) Adoption and Benefits of Management Accounting Practices: An Inter-Country Comparison. Accounting in Europe 9: 95-110. DOI:10.1080/17449480.2012.664394 